\title{
Reducing Unemployment, Poverty and Promoting Empowerment through Skills Acquisition (TVET): A Case Study of Returnee Migrants
}

ISSN: 2311-8636 (Print)

ISSN: 2312-2021 (Online)

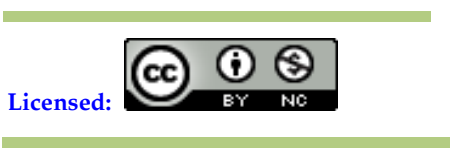

Source of Support: Nil

No Conflict of Interest: Declared

*Email for correspondence:

17010194@siswa.unimas.my

\section{Onyekachi Ohagwu*, Zamri bin Hj Hassan, Dolly Paul Carlo}

Faculty of Social Sciences and Humanities, Universiti Malaysia Sarawak, MALAYSIA

\section{ABSTRACT}

This paper explains recent statistics and phenomena related to returnee migrants in Edo state, Nigeria. The significance of this paper is that it creates awareness on causes and motives behind irregular migration leading to repatriation (returned migrants). Based on data gathered from most research participants (returnee migrant) - the quest to improve one's socioeconomic living conditions are the motives behind most Nigerians' migration journey (regular or irregular) to western countries (i.e., Europe, Canada, USA, etc.). The socioeconomic imbalance in Nigeria is mainly caused by the high rate of unemployment and poverty; thus, the majority of Nigerians are of the opinion that migrating to western countries, is a potential pathway to an improved socioeconomic living condition. This paper further suggests - skill acquisition (TVET) as an approach to reduce unemployment and poverty; thus, economically improving the socioeconomic living conditions of the majority of Nigerians.

Keywords: Migrants, Returnee migrants, Poverty, Unemployment, Skill acquisition (TVET), and Empowerment

\section{INTRODUCTION}

In Nigeria, cases of returnee migrants' gory tales have become a thing to worry about. A typical example was the infamous 'Libya slave-trade' saga, where migrants en-route European countries, were held hostage and or slave-traded at their transit point, Libya. Some of the 'Libya slave-trade' victims (migrants) were repatriated to their respective countries; with over $90 \%$ of the overall migrants being of Nigerian nationality, thus repatriated to Nigerians (see: CNN, 14 November 2017; IOM, 2018).

This incident led both the federal, state government, international and national nongovernmental organizations (NGOs) in Nigeria to establish productively engaging activities to boost the socio-economic living conditions of Nigerian returnee migrants. For instance, the Edo state government established Edo State Taskforce Against Human Trafficking (ETAHT) - an agency that among other things have collaborated with NGOs (i.e., IOM, etc.) to organizes skill acquisition (TVET) programmes for returnee migrants; in order to equip them with skills that would be productively and financially rewarding to the participants (returnee migrants) in the future. 
In explaining the statistics, discussing the factors leading to returnee migrants and postulating possible solutions to address the related social problems, it is imperative to clarify that this paper's statistical data (primary and secondary) were gathered from a research study on returnee migrants in Edo state, Nigeria.

However, it is pertinent to first explain these key terms - "migrant," and "returnee migrant." International Organisation for Migration (IOM) 'defines as;

'migrant as any person who is moving or has moved across an international border or within a State away from his/her habitual place of residence, regardless of (1) the person's legal status; (2) whether the movement is voluntary or involuntary; (3) what the causes for the movement are; or (4) what the length of the stay is' and 'some migrant moves in search of work and economic opportunities' (2019).

After an in-depth interview with research participants, this paper opines that a "migrant" is an individual who either legally or illegally resides in a state or country other-than theirs - by birth-origin or nationality; with an intention to either stay temporary or permanently. While most people seek or become migrants in order to improve their economic living conditions, others migrate due to social and or political unrest in their states or countries of origin.

IOM (2011) and UNESCO (2017) classified a returnee migrant as an irregular migrant repatriated to his/her country or points of initial migration departure. European Parliamentary Research Service EPRS (2017) elaborates that a returnee migrant is 'a person who returns to their country of citizenship after having been an international migrant (whether short-term or long-term) in another country, and who intends to remain in their own country.'

Therefore, this paper submits that a "returnee migrant" is a migrant - who is voluntarily or involuntarily repatriated either from their migration transit or destination points to their country of birth-origin, nationality, or the points of their first departure/disembark. A returned migrant is considered an irregular migrant, hence their repatriation.

\section{Nigerian Returnee Migrants Statistics}

According to statistics between April 2017 - May 2018, International Organisation for Migration (IOM) in Nigeria collaborated with Federal Government agencies, Nigerians in Diaspora Commission (NiDCOM) and National Commission for Refugees Migrants and Internally Displaced Persons (NCFRMI) successfully repatriated over eight thousand $(8,000)$ Nigerian returnee migrants - with over seven thousand $(7,000)$ returned from Libya (IOM, 2018).

Table 1: Nigerian Returnee Migrants Repatriation Points (2017-2018)

\begin{tabular}{|l|l|l|}
\hline Repatriation points & Frequency & Percentage \\
\hline Libya & 7000 & $87.5 \%$ \\
\hline Others & 1000 & $12.5 \%$ \\
\hline Total & $\mathbf{8 0 0 0}$ & $\mathbf{1 0 0} \%$ \\
\hline
\end{tabular}

Source: IOM, 2018. Note: “Others" represents migrants repatriated from other countries except Libya.

Table 1 shows a sum total of 8000 Nigerians repatriated from different points; with Libya recording the highest in percentile $(87.5 \%)$ reaffirmed the horrible "Libya-slave-trade" saga (Ibid). 
Supporting the above statistics, is a more recent statistics presented to the researcher by NCFRMI's Head of Migration Unit, Alexander Oturu - NCFRMI note that as of January 2020 its' agency has solely repatriated 2,130; while in collaboration with IOM, they repatriated 17,300; making the total number 19,430 Nigerians returnee migrants from Libya (Oturu, 2020).

Table 2: Nigerian Returnee Migrants from Libya (January, 2020)

\begin{tabular}{|l|c|c|}
\hline Migrant Agencies & Frequency & Percentage \\
\hline NCFRMI/IOM & 17,300 & $89.03 \%$ \\
\hline NCFRMI & 2,130 & $10.96 \%$ \\
\hline Total & $\mathbf{1 9 , 4 3 0}$ & $\mathbf{1 0 0} \%$ \\
\hline
\end{tabular}

Source: Oturu, 2020; Key informants' research question 4.

While a total of 19,430 Nigerians have been repatriated from Libya through the collaboration of NCFRMI and IOM; the Edo State Government through ETAHT received 5,114 (Male-3,402; female-1,473; and children-239) returnees, which is the largest number of returnee migrants per state in Nigeria (ETAHT, 2020).

Table 3: Edo State Returnee Migrants (January, 2020)

\begin{tabular}{|l|c|c|}
\hline Edo State & Frequency & Percentage \\
\hline Edo State & 5,114 & $26.32 \%$ \\
\hline Total (Federal) & $\mathbf{1 9 , 4 3 0}$ & $\mathbf{1 0 0} \%$ \\
\hline
\end{tabular}

Source: ETAHT, 2020.

Nigeria is a country that is made up of 36 states including the Federal Capital Territory (Abuja) and Table 3, shows that Edo state had over one quarter percentile $(26.32 \%)$ of the total federal returnee migrants and unarguably being the state with the highest returnee migrants is worrisome. Above all, the fact that as at the time of writing this paper, Nigeria has a total of 19,430 returnee migrants - is a thing of great concern, which causes has been attributed to the high rate of unemployment and poverty in Nigeria.

\section{LINKING UNEMPLOYMENT AND POVERTY TO RETURNEE MIGRANTS}

Unemployment and poverty has become a continuous social problem confronting Nigeria. The alarming increase of unemployment rate in Nigeria is approaching if not already at the pandemic stage. In 2018 Nigeria's National Bureau of Statistics (NBS) reported an unemployment rate of 23.1 percent in the third quarter of 2018 - this figure increased to $27.1 \%$ in the second quarter (Q2), 2020; and 33.3\% in the fourth quarter (Q4), 2020 respectively (National Bureau of Statistics NBS, 2018, 2021). In 2021, NBS also reported $42.5 \%$ youth unemployment/underemployment in the fourth quarter (Q4) of 2020 (Ibid).

There are limited availability of exclusive previous study and or resources that collectively or simultaneously argues on this paper's subject matters (skill acquisition (TVET), employment, empowerment, poverty and returnee migrants) in Nigeria. However, this paper has a closer study argument by Oxford Business Group (2013) and Fund (2014) where they argued that TVET programmes as a facilitator of employment and empowerment has become elusive, especially in developing countries. They further opined that most youths do not fancy TVET, thus are nonchalant toward participating in the training programmes. However, data gathered from this study countered the above notion, as all its research participants fall within the Nigerian youth bracket (18-35) who 
have jettisoned the "youth do not fancy TVET" views, and chosen to acquire TVET skill graduated and became self-employed through the ETAHT TVET programmes, hence out of the Nigeria's unemployment index.

Although Nigeria is still plagued with unemployment, this paper through its study can confirm that ETAHT TVET programmes and many other TVET programmes across Nigeria has facilitated the employment and self-employment of the majority of Nigerians including Nigerian returnee migrants. This is factual as a great percentage out of TVET programmes graduates in Nigeria have become self-employed. For instance, while, $83.33 \%$ of this paper's research participants asserts, that ETAHT TVET facilitated their selfemployment; $50 \%$ stressed that ETAHT TVET leads to their empowerment - hence lifted out of poverty.

Still on poverty in Nigeria - in 2018, World Poverty Clock (WPC), a Vienna-based NGO that provides real-time poverty data across countries - conducted research and published its findings on global poverty. In their report on Nigeria, WPC noted that 'Nigeria now has more people living in extreme poverty than any other country in the world' (2018). More recently, WPC reports that approximately 90 million Nigerians (43\% of Nigeria's population) are "living in extreme poverty" - below the international poverty threshold of $\$ 1.90$ per day (2020). The above statistics reflect the level of economic imbalance, thus a major reason, people embark on economic migration in search of greener pastures overseas (Walker, 2010).

Unemployment and economic imbalance plays a major part in contributing to poverty in Nigeria and the world, resulting in irregular migration - now a global crisis. Although over the last few decades, economists have tried to find a solution to eradicate poverty, especially since the United Nations' Sustainable Development Goals (SDG) were launched - targeting to end poverty in all its forms everywhere (Mansi, et. al. 2020).

However, within the context of this study - Nigeria; a study conducted by Oshionebo (2017) opined that corruption and public finance mismanagement are key impediments to the efficiency level of projects like skills acquisition programmes in Nigeria. The study notes that a reduction or eradication of poverty corruption and mismanagement of finance will help to boost economic development in Nigeria. According to Oshionebo, corruption and mismanagement of public finance has cast public doubts about the efficacy of government projects (i.e. TVET programmes) that targets improvement of the economic living conditions of the majority of Nigerians. Although there are still pockets of complaints about corruption, mismanagement of public finance and high poverty rate in Nigeria which need to be addressed through a macroeconomic strategy; however, on a micro-level - this study opines that the ETAHT TVET programmes and other similar programmes nationwide, have impacted significantly towards the lifting of some Nigerians - including returnee migrants from poverty.

At this junction, it is imperative to discuss in details - Nigeria's returnee migrants' related phenomenon - unemployment and poverty. The alarming unemployment and poverty statistics has become of great concern to Nigerians, to which the Federal Government of Nigeria, Edo State Government, and non-government organizations have been working together to address - in order to nip-in-the-bud the root causes of irregular migration. This study believes that the constant reoccurrence of returnee migrant and related problems are due to economic challenges (unemployment and poverty) confronting a high percentage of Nigerians. 
Therefore, identifying and proffering solutions to mitigate the underlying factors leading to irregular migration and subsequent repatriation of migrants is essential - hence through in-depth interviews, this paper ascertained that due to the rise in unemployment, poverty rate and ultimately high level of socioeconomic imbalance were the core reasons for migration. This study's research participants opined that the quest to attain improved socioeconomic living conditions necessitates the urge by most Nigerians' migration to western countries.

For instance, a CNN (2018) report notes that although Nigeria is the largest economy in Africa - it is ironically ranked as the country with the largest number of people living in extreme poverty, with an estimated 87-102 million Nigerians, around half of the country's population thought to be living on less than $\$ 1.90$ a day (also see: World Bank, 2017; World Poverty Clock, 2018, 2020).

Hence, Nigeria's adverse economic revelations significantly contribute to some Nigerians irregular migration to Europe in search of greener pasture. However, a few of these irregular migrants end up being repatriated back to Nigeria - with an uncertain destiny ahead, which might make them (returnee migrants) become vulnerable to all sorts of social vices and or criminal activities.

\section{ENGAGING RETURNEE MIGRANTS THROUGH TVET PROGRAMMES}

In Nigeria, the need to address challenges associated with returnee migrants necessitated the establishment of federal and state government agencies saddled with the responsibilities of ensuring that the welfare of returnee migrants is given top priority (visà-vis, repatriation, rehabilitation, and reintegration). In addition, some state governments for instance, and as earlier mentioned, from August 2017 to January 2020, the Edo state government through ETAHT received over 5000 returnee Migrants (ETAHT, 2020). Subsequently, ETAHT in collaboration with non-governmental organizations like IOM has trained returnee migrants in different skills through its established skill acquisition programmes, particularly technical vocational education and training TVET centres like Agricultural Development Programme (ADP), Centre for Edo Delta Development Initiative (CEDD) and Edo State/United Nations Development Programme (UNDP) partnership on youth empowerment drive targeting returnee migrants from Edo State (Ibid).

As of November 2019 - IOM single-handedly completed business training for 9,929 returnee migrants in different vocational "business skills training;" while in a collaborative effort, ETAHT and IOM also train and provided stipends for business start-up respectively for close to 2,000 returnee migrants in Edo state (Galindo, 2020; ETAHT, 2020).

Such measures according to UNDP's Country Director Samuel Bwalya is solely aimed at empowering returnee migrants with TVET skills. Bwalya further notes that the organization's partnership with the Edo state government specifically targets at equipping Edo State's returnee migrants with technical and vocational skill, as it sees such platform (skill acquisition) as a key to dissuading returnee migrants from social vices (Bwalya, 2018).

According to Ohagwu, (2020) TVET is a pathway to empowerment. This is because skill acquisition (TVET) is a training process that equips participants with hands-on skills and knowledge; thus, enables them (TVET participants) to utilize acquired skills to earn a living and subsequently, improve their socio-economic living conditions. This paper's 
study further notes that TVET programmes have helped in the transformation of skills and knowledge into creative ventures, especially among the majority of returnee migrants (research participants) in Edo state - who considered themselves to have been empowered through the Edo State Taskforce Against Human Trafficking (ETAHT) and the International Organization for Migration's (IOM) collaborated TVET programmes for returnee migrants in Edo state.

Furthermore, writers' views on empowerment, coupled with in-depth interviews and data gathered from research participants; this study asserts that empowerment is the capabilities (TVET) individuals or groups possess and channelled into productive use thus enabling them to improve their socio-economic living conditions. The productive usage of skills acquired through TVET programmes facilitates individuals and groups selfreliant - typically considered a crucial step towards empowerment.

Based on the study conducted, this paper asserts that, the ETAHT TVET programmes approach successfully facilitated the productive engagement and empowerment of most returnee migrants (research participants) - thus reduces unemployment, lifted a high percentage of this study's research participants from poverty and boosted their economic empowerment (table, 4).

Table 4: Returnee Migrants' Post TVET Empowerment Scale

\begin{tabular}{|l|c|c|}
\hline Empowerment Status & Frequency & Percentage \\
\hline Empowered (E) & 15 & $50 \%$ \\
\hline Partially Empowered (PE) & 10 & $33.33 \%$ \\
\hline Not Empowered (NE) & 5 & $16.66 \%$ \\
\hline Total & $\mathbf{3 0}$ & $\mathbf{1 0 0} \%$ \\
\hline
\end{tabular}

Source: Section C: Question 4.

As can be seen from table 4 , in a total of 30 research participants, half (15) of the research participants (returnee migrants) considered themselves empowered, while, 10 and 5 research participants opined that they are partially empowered (PE) and not empowered (NE) respectively. The pie chart (figure, 1) below, further explains the percentile of research participants that were empowered, partially empowered and not empowered by the ETAHT TVET programmes.

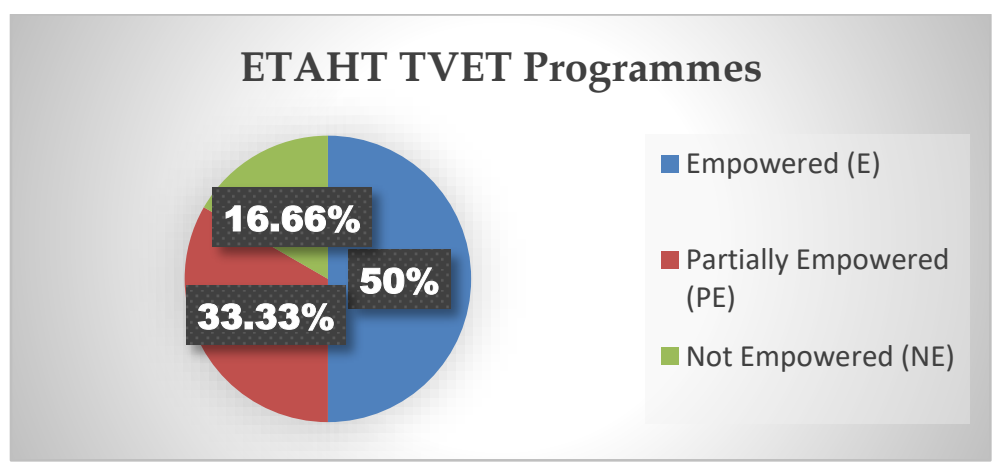

Figure 1: ETAHT TVET Programmes Empowerment Percentile Source: Section C: Question 4.

Similar to a previous study by Ohagwu (2020), which noted that $90 \%$ of the study participants agreed that "TVET lead to empowerment" - majority of this paper's study 
research participants (returnee migrants) opined that TVET programmes are pathways to empowerment. The chart representation above (Figure 3.1) shows that 50\%, 33.33\% and $16.66 \%$ of the study's research participants were "Empowered" (E), Partially Empowered (PE), and "Not Empowered" respectively by the ETAHT TVET programmes. During the in-depth interviews, the researcher was able to understand from research participants what they gauged or considered - empowered, partially empowered, and not empowered.

Majority of the research participants believed that being "empowered" is the ability to make full use TVET skills acquired to productively work and earn a living that has helped them meet their financial obligations and also able to save a reasonable percentage of their earnings - in case of unforeseen circumstances (emergencies). While "partially empowered" is considered as working and earning a living without the abilities to save a reasonable percentage of one's earning either due to marital or family status and or obligations. This paper's research participants' that considered themselves "not empowered" by ETAHT TVET programmes are those who faulted the insufficient start-up fund they received after graduating from the TVET programmes; and also not forgetting the lack of regular supervision and monitoring of their business progress (success or otherwise) by the TVET programmes officials.

\section{POLICY IMPLICATIONS}

Nationally, corruption and mismanagement of public finance is still a major problem in Nigeria - hence this paper suggests an independent audit team to regularly audit funds allocated to TVET programmes in Nigeria and ensures it is rightly spent.

\section{Youth}

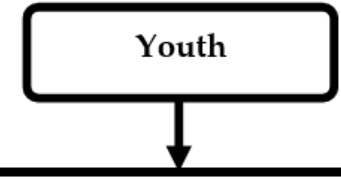

Technical and Vocational Education and Training (TVET) Proorammes (i.e.. TEGAS)

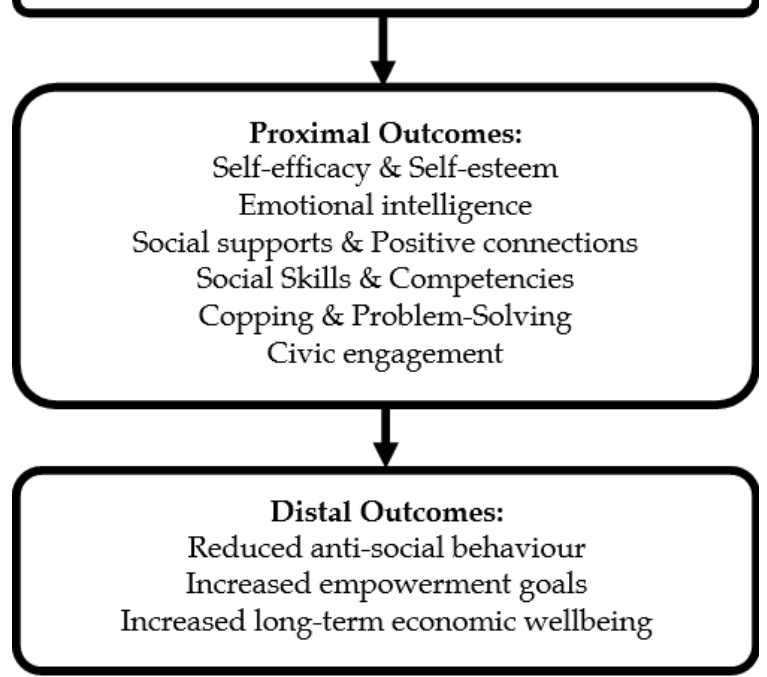

Figure 2: Youth Empowerment Process Concept Source: Ohagwu, (2020) adapted from Keiffer's (1984 cited in Essay, UK 2013) 
Globally, this study is important to the international audience, because migration issues cut across different continents and to avoid global migration crisis - the collective efforts of international government and non-governmental organization are required to address the regular influx of irregular migrants to most western countries. For instance, all of this study's research participants (returnee migrants) headed to Europe through Libya, and to avoid global migration crisis, it is imperative to address it both from the grassroots (point of dis-embarking) to the global level (transit and or destination points).

Adopting a practical framework will go a long way at addressing related issues - this was postulated in empowerment aimed TVET conceptual framework by Ohagwu (2020), where he illustrated the processes and outcomes of skill acquisition (see, figure 2).

The above "youth empowerment process concept" explains that a comprehensive empowerment inspired TVET strategy or programmes targets a robust socio-economic environment for an individual(s) and society.

With the knowledge; literature, theoretical framework, and data gathered from previous studies, this paper proposes the below framework - illustrating how individual(s) with TVET skills helps in the reduction of unemployment, poverty and promotes empowerment.

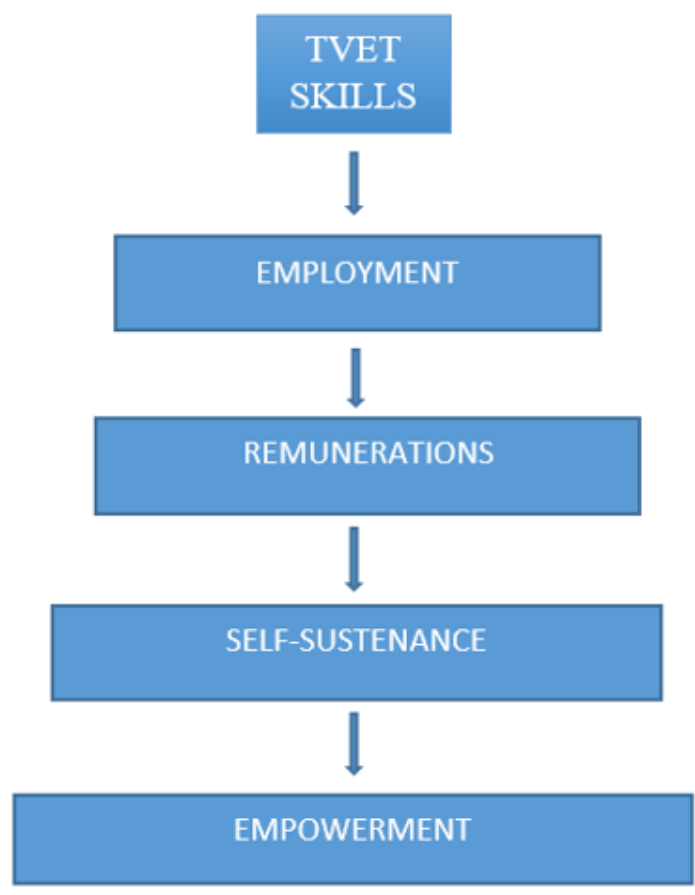

Figure 3: TVET - Employment - Empowerment Model

Within the context of TVET, the above diagram illustrates the role of TVET in facilitating the employment and empowerment of individual(s) - thus reduces unemployment and poverty. In explanation -- the possession of TVET skills are key EMPLOYMENT requirement; and the rewards for employment are REMUNERATION - consistent REMUNERATIONS (salaries, wages, and allowances), lead to the level of individual(s) SELF-SUSTENANCE which is considered EMPOWERMENT. 
Figure 3 among other academic knowledge was added to this study, after identifying the gaps in previous literature studied, and data gathered from this study - in order to provide a broader and contemporary understanding of this study's subject matter, like returnee migrants. TVET, employment and empowerment and also present a tested practical framework.

\section{CONCLUSION}

This paper notes that TVET programmes are an important empowerment catalyst therefore, this paper suggests that policymakers and stakeholders should regularly update themselves with the latest comprehensive practical frameworks that focus on empowerment through TVET; as it will help them (policymakers and stakeholders) to possess adequate knowledge required in addressing contemporary TVET and empowerment-related issues. Also, policymakers and stakeholders should regularly review post TVET programmes start-up funds and ensure that TVET programmes graduates are set up with sufficient funding for efficient and sustainable operations.

Finally, doing all the above suggestions will be productively engaging and financially rewarding to returnee migrant, hence improving their socioeconomic living conditions; while also reducing the unemployment and poverty statistics in Nigeria.

\section{REFERENCES}

Bwalya, S. (2018). Illegal Migration: UNDP collaborates with Edo Government to empower youths. Retrieved on 14 April, 2021. https://www.pmnewsnigeria.com/2018/03/20/illegal-migration-undpcollaborates-with-edo-govt-to-empower-youths/

Cable News Network CNN (2017). People for sale: Exposing migrant slave auctions in Libya. Retrieved on 15 April, 2021. https://edition.cnn.com/specials/africa/libya-slave-auctions.

Cable News Network CNN (2018). Nigeria overtakes India in extreme poverty ranking. Cable News Network CNN. Retrieved on 15 April, 2021. https://edition.cnn.com/2018/06/26/africa/nigeriaovertakes-india-extreme-poverty-intl/index.html.

Edo State Taskforce Against Human Trafficking ETAHT (2020). ETAHT report 2020. Edo State Taskforce Against Human Trafficking.

Essays, UK. (November 2013). Define Empowerment Capacity Building And Participation $\begin{array}{lllll}\text { Psychology } & \text { Essay. } & \text { Retrieved } & 18 & \text { September, }\end{array}$ https://www.ukessays.com/essays/psychology/define-empowerment-capacity-building-and-participationpsychology-essay.php?cref=1

European Migration Network EMN (2015). Challenges and good practices in the return and reintegration of irregular migrants to West Africa. European Commission.

European Parliamentary Research Service EPRS (2017). Reintegration of returning migrants. Brussels: European Union. $\quad$ Retrieved 2021. https://www.europarl.europa.eu/RegData/etudes/BRIE/2017/608779/EPRS_BRI(2017)608779_EN.pdf

Fund, B. M. (2014). The risks of investing in SCORE and Sarawak dams. Switzerland: Bruno Manser Fund.

Galindo, J. (2020). International Organization for Migration: Nigeria report 2020. International Organization for Migration.

International Organization for Migration IOM (2011). International Migration Law: Glossary on Migration ( $2^{\text {nd }} E d$.). Geneva: International Organization for Migration.

International Organization for Migration (2017). UN Migration Agency, EU partner to provide returning Nigerian migrants with reintegration assistance. International Organization for Migration. 
International Organization for Migration (2018). Over 8,000 Nigerian migrants return home with IOM assistance in past 12 months. Retrieved on 15 April, 2020. https://www.iom.int/news/over8000-nigerian-migrants-return-home-iom-assistance-past-12-months

International Organisation for Migration IOM (2019). New projects aims to scale up reintegration assistance to returnees in Nigeria. Retrieved on 15 April, 2021. https://www.iom.int/news/newproject-aims-scale-reintegration-assistance-returnees-nigeria.

Keiffer, C. (1984). Citizen empowerment: A developmental perspective. Prevention in Human Services, $3(16), 9-35$.

Mansi, E., Hysa, E., Panait, M. and Voica, M. C. (2020). Poverty - A challenge for economic development? Evidences from western Balkan countries and the European Union. MDPI Sustainability Journal, Volume 12 (7754), 1-24.

National Bureau of Statistics (2017). Labour Market, Unemployment rate. Nigeria: National Bureau of Statistics. http://www.nigerianstat.gov.ng/

National Bureau of Statistics NBS (2018, 2021). NBS - E-Library. Retrieved on 14 April, 2021. https://nigerianstat.gov.ng/elibrary?queries[search]=unemployment

National Commission for Refugees, Migrants and Internally Displaced Person NCFRMI (2020). Distribution of returnee migrants from Libya by state (February 2017 - May 2018). Nigeria: National Commission for Refugees, Migrants and Internally Displaced Person (NCFRMI).

Ohagwu, O. M. (2020). Technical training: A pathway to youth empowerment. International Journal of Science and Technology, 6(1), 101-112.

Organization for Economic Co-operation and Development OECD (2012). Poverty reduction and propoor growth: the role of empowerment. Organization for Economic Co-operation and Development.

Oshionebo, E. (2017). Mismanagement of Nigeria's oil revenues: is the Nigeria Sovereign Investment Authority the panacea? The Journal of World Energy Law \& Business, Volume 10 (4), 329-347.

Oturu, A. (2020). Returnee migrants report 2020. Nigeria: National Commission for Refugees, Migrants and Internally Displaced Person (NCFRMI).

Oxford Business Group (2013). 'The Report Sarawak 2013.' Oxford Business Group.

United Nations (2013). United Nations World Report: Youth and Migration. United Nations.

United Nations Department of Economic and Social Affairs UNDESA (2012). Empowerment: What does it mean to you? United Nations Department of Economic and Social Affairs (UNDESA).

United Nations Educational Scientific and Cultural Organisation UNESCO (2017). Migration as a development challenge: analysis of root causes and policy implications. United Nations Educational Scientific and Cultural Organisation (UNESCO).

Walker, R. (2010). Pushes and Pulls: Why do people migrate? USA: Crabtree Publishing Company

World Bank (2017). Poverty and equity data: Nigeria. Switzerland: Retrieved on 15 April, 2021 >> http://povertydata.worldbank.org/poverty/country/NGA

World Bank Group (2017). Country Poverty Brief: Sub-Saharan Africa - Nigeria. Work Bank.

World Poverty Clock WPC (2018; 2020). Nigeria. Retrieved on 14 April, 2021 >> https://worldpoverty.io/map

Online Archive

https://i-proclaim.my/journals/index.php/ajhal/issue/archive 